\title{
Making Space a Home: Role of Homeland-Based Cultural Practices in Homemaking of Tamils and Somalis in Norway
}

\author{
Sarvendra Tharmalingam ${ }^{1}$ \\ ${ }^{1} \mathrm{PhD}$ in Human Geography, post-doctoral research fellow at the Department of Sociology and Human geography at \\ University of Oslo, Norway. \\ Correspondence: Sarvendra Tharmalingam, PhD in Human Geography, post-doctoral research fellow at the Department \\ of Sociology and Human geography at University of Oslo, Norway.
}

Received: June 1, 2014

doi:10.11114/ijsss.v4i6.1620
Accepted: April 21, 2016

Available online: May 20, 2016

URL: http://dx.doi.org/10.11114/ijsss.v4i6.1620

\begin{abstract}
This article looks at the relationship between homeland-based cultural practices and the homemaking process of first-generation members of the Tamil and Somali diaspora communities in Norway. There are around 13000 Tamils and 25000 Somalis currently living in Norway, adopting practices and habits that are culturally rooted in the lifestyle of their country of origin. This article does not see country-of-origin orientation and home in Norway as opposites, but rather as complementary processes. Thus, this article argues that homeland-based cultural practices of Tamils and Somalis are part of their homemaking in Norway to establish a space of comfort. The main empirical base of the paper is grounded in 40 interviews of first-generation immigrants, 25 of Tamils and 15 of Somalis.
\end{abstract}

Keywords: Home, Tamils, Somalis, Cultural practices, Norway

\section{Introduction}

\subsection{Where is my home?}

"I was nervous when I went back to my home after 15 years abroad. It was the place I was born and brought up. In the house I had a room with my books, my bed, a reading table, etc. My memories were filled with the years we lived together there as a family: parents and four children, two male and two female. Now I lived in Norway, my brother in Canada, one of my two sisters in the UK. My youngest sister was doing her Masters degree at the University of Peridenya, one of the leading universities in Sri Lanka, located in the central part of the country while her husband was working in Dubai. My mother lived with my sister. When I visited my village, I had no family members living there anymore.

"I arrived in the village and slowly approached the gate of my home. I knew that the house was rented out and some others were living there. I called out loudly, 'Veedukarar.' 1 A middle-aged woman came. I said, 'This is the place where I was born and brought up and lived for 25 years. May I come in and see it?' She agreed and I entered. It was a big shock for me. This was no longer the place where I grew up. My room was filled with coconuts. All the rooms, hall and kitchen were in bad shape and did not even have a sign of our 25 years of life there. It was no longer my home."

This was my experience when I visited my childhood home in war-torn Northern Sri Lanka in 2003 after having lived in Norway for 15 years. Not only did I experience the feeling of having lost my home, the visit also revealed changes that had occurred during the last 15 years in my village, in the region, as well as in the whole country. In my village, houses and buildings had been destroyed by the war. A railway line nearby had disappeared completely. No friends were living in the village anymore. Almost everybody had migrated or was internally displaced. I was able to visit only three relatives instead of more than fifty who had been there in 1988. While I visited the village, I enjoyed a Tamil New Year celebration for a few minutes in which less than 500 people participated, although more than 5000 people had participated in the years before the armed conflict escalated in 1983. None identified me during the time I was

\footnotetext{
${ }^{1} \mathrm{~A}$ Tamil word that denotes person or persons who own the house or live in the house.
} 
observing the festival and surroundings. I left my home village feeling alien. This experience made me think about the relationship between house and home, as well as between home and homeland in the context of transnational migration.

\subsection{Scope of the study}

This article is not about returning migrants and their experiences of home. Rather, I focus on the homemaking processes of diaspora communities in their country of settlement. How do diaspora members establish a sense of home in their new country of choice? What facilitates the homemaking process? Based on a thematic analysis of data from interviews with 40 migrants from Sri Lanka and Somalia living in Oslo, this article addresses the dynamics of homemaking in Norway.

In the literature of diaspora and transnationalism, the relationship between making a home in the country of settlement and maintaining homeland orientation and connection is often seen as alternative and/or opposite processes. It is argued that a strong homeland orientation of diaspora communities might have negative effects on integration in the host society (Fuglerud 1999). Moreover, it is considered that "failures of successful integration" in the host society could induce a stronger homeland orientation, which by some is described as "reactive transnationalism" (Itzigsohn and Saucedo 2002). This article studies the process of homemaking from a different angle. It suggests that the process of making a home in a new country, on the one hand, and culturally based homeland orientations on the other are not opposite but complementary processes (Morawska 2003, Levitt 2003)

\subsection{Methods of data collection}

The empirical data for this article were collected during the years of 2007-2008 through 40 interviews with first-generation immigrants, 25 Tamils and 15 Somalis living in Norway. The interviews were taken in different settings, some in the family home, some at a public place such as restaurants and malls and some others at an institutional setting where the interviewees (Somalis) were attending Norwegian and other courses targeting labour markets. Interviews with Tamils were conducted in the Tamil language since the author is a native Tamil speaker. Interviews with Somalis were conducted in three languages: English, Norwegian and Somali, the last with the help of an interpreter, who is also a social researcher. Two focus group discussions were held with Tamils in Oslo in order to discuss their perspectives on homeland-based cultural practices. A focus group discussion could not be held with the Somalis due to practical difficulties and language barriers. Participant observation, done at the time of interviews and cultural functions has been used as support material for the data collected through interviews. Data were analysed on a thematic basis.

\section{Home as a multidimensional concept}

The concept of home and homemaking among diaspora communities is an old issue; seeing the process through a transnational optic, however, is a recent phenomenon among scholars (Cheran 2006, Yeoh et al 2003, Ali and Koser 2002, Graham and Khosravi 1997).

Home is a concept that has multiple meanings. Mallett (2004) discusses different aspects of home by making a critical literature review on the term 'home' as it is used within different academic disciplines. In her conclusion, she observes:

Clearly the term home functions as a repository for complex, inter-related and at times contradictory socio-cultural ideas about people's relationship with one another, especially family, and with places, spaces, and things. It can be a dwelling place or a lived space of interaction between people, places, things; or perhaps both. (Mallet 2004: 84)

She further summarises that the "boundaries of home are permeable and/or impermeable" and home can be "singular and/or plural, alienable and/or inalienable, fixed and stable and/or mobile and changing". She finds that literatures further link home with "feelings of comfort, ease intimacy, relaxation and security and/or oppression, tyranny and persecution". (2004:84) Home can thus be associated with family in some cases and not in others.

Mallett shows us that home is very broad concept accommodating a variety of meanings. In this article, I will analyse the processes of homemaking. Therefore, it is particularly useful to use perspectives on home dealing with the relationship between space, place and home.

\subsection{Home and house}

It will be useful to start our contextualization by making a distinction between home and house. As I narrated my experience on the visit to my childhood home after 15 years of exiled life, I lost my home, but not the house. The physical building, although with some damage, had survived the war.

"With money you can buy a house, not a home" proclaims a Chinese proverb. Making a distinction between home and house, the latter being a thing that can be bought, it denotes lack of family and social relations in the term house. Without directly mentioning family and social relations with respect of the term home, the proverb implicitly stresses the difference between house and the home by adding aspects of relations toward the term home in an implicit way. 
Saunders and Williams define home as "simultaneously and indivisibly a spatial and a social unit of interaction" (1988:82). For them home is the physical setting where "basic forms of social relations and social institutions are constituted and reproduced" (1988:82). According to them home involves not only the physical settings but also social settings.

These definitions give us clarity on the basic distinction between home and house: home is a spatial and social unit where family and social relations and institutions are produced, reproduced and negotiated, whereas house is only a spatial unit, a physical setting. In the context of this article, the term home is used as a spatial and social unit with social interactions.

\subsection{Space, place and home}

The other aspect that is relevant for this article is the relationship between space, place and home. As we have seen above, home is a multidimensional concept that covers a wide range of interpretations; this article is limited to interpretations and definitions of home that links space and place. Short says:

The home is a key site in the social organisation of space. It is where space becomes place and where family relations and gendered class identities are negotiated, contested and transformed. The home is an active moment in both time and space in the creation of individual identity, social relations and collective meaning. (Short 1999: x)

Short indicates a relationship between space, place and home. Home is created where space is turned into place. Home evolves when a spatial unit also becomes a social unit where social relations and identities and collective meaning are created. How does a space become a place? Creswell (2004) illustrates it with an example:

Cast your mind back to the first time you moved into a particular space - a room in college accommodation is a good example. You are confronted with a particular area of floor space and a certain volume of air. In that room there may be a few rudimentary pieces of furniture such as a bed, a desk, a set of drawers and a cupboard. These are common to all the rooms in the complex.... A common strategy is to make the space say something about you. You add own possessions, rearrange the furniture within the limits of the space, put your own posters on the wall, arrange a few books purposefully on the desk. Thus space is turned into place. Your place. (Creswell 2004:2).

Thus, space becomes place when meaning is added to the particular space by purposefully locating objects and personal possessions within it. Angew (1987) outlines three fundamental features through which a place becomes meaningful: location, locale and sense of place. Location is the geographical position of the place. Locale, for Angew, refers to the material setting of the place where social relations take place. Sense of place is the subjective experience of the people who live in or interact with the particular place: their feelings, emotions and attachments. When a place becomes a meaningful location, then it becomes home. This is the way people make space into place and then home. Such a place gives comfort, as people make a home by "the establishment of [a]space of comfort." (Wise 2000: 297)

Home is also understood in relation to practices. Within this meaning, Douglas (1999) defines home as follows:

[Home began as] a pattern of regular doings, furnishings and appurtenances, and a physical space in which certain communitarian practices were realised. Home began by bringing space under control and thus giving domestic life certain physical conditions: directions of existence. (Douglas 1991: 290)

Wise (2000) describes home as a space of comfort, but argues that home is not the place we come from but where we are.

... a home [is] the establishment of a space of comfort. Home is not an originary place from which identity arises. It is not the place we 'come from'; it is a place we are. (Wise 2000: 297).

The definitions of home given by Wise and Douglas as the "establishment of [a] space of comfort" and a space that facilitates communitarian practice by bringing that space under control, respectively, have the most relevance in relation to the issues discussed in this article.

The discussion so far leads to the question: Are place and home the same? While discussing the place as home, Creswell (2004) notes that 'home is an exemplary kind of place where people feel a sense of attachment and rootedness'. In this sense, we can say home is a particular kind of place. This brings us to another question. Can the process of place making and homemaking be similar? Since a space becomes a meaningful place, then it could also be considered a home. In making meaning of a place, according to Angew, location, locale and sense of place are fundamental. In the context of this article, our location is Norway, a North European, Scandinavian country. The material settings of Norway represent the locale and the affiliations of the people towards Norway represent the sense of place. 


\section{Place making and homemaking of migrants}

When migrants arrive in a new country, they enter into a new space that is not familiar to them. They start their life by learning the language, adopting the system and the practices of the country in which they settle down. In the context of this article, Norway is the new space and Tamils and Somalis are the migrants. It takes time for such an adaptation, often described as immigrant adaptation or incorporation process. Assimilation, multiculturalism, exclusion and integration are different forms of adaptation that have been discussed with regard to immigrant adaptation (Park 2008, Gordon 1964, Kymlicka 1996, Tambiah 2002, Portes and Zhou 1993, Faist 2000). These concepts are defined from above by policy makers in the new country. From the migrants' point of view, they are slowly getting to know the new space and becoming familiar with it. From the issues of how to use the public transport, learning cultural codes of mainstream society and how to deal with the bureaucracy of the new country - all this are part of the process of their attempt to become familiar with the space. This paper sees this process as the place making process of migrants.

When migrants start their lives in the new country, they enact homeland-based cultural practices that are part of their life style and identity. At the beginning, especially for asylum seekers and refugees, it is difficult to know for how long they would have to live in Norway, their new country of residence. Several of my informants say that at arrival, they never intended to settle in Norway for a long period of time. They were full of nostalgia and organised their life in a way that would facilitate their return when the time came. As time went by, they slowly realised that they would have to live in the new country for a longer period. They realised that they had to make the new country into a place of comfort for themselves. They wanted to reproduce their cultural practices and institutions in a more organised, collective way in order to transform / reinvent the new space of living into a comfortable place or into another home. This is what I call the homemaking process of migrants.

Distinguishing place making and homemaking in the context of migration may require more explanation. Making space familiar and comfortable is often described as place making (Cresswell 2004). It seems, however, and especially for migrants, that the concept of place making does not fully cover the complex reality of how they organise their life. Socially, organising space has at least two dimensions. The first is to organise space with the social and cultural resources readily available within the existing space, which is called place making. The second is to organise it with the social and cultural resources that they have brought with them or are available to them from outside of the national borders of Norway. Contemporary migrants, who have often been described as disaporas and transnational communities, do not restrict their social space to the territorial borders of the new country of settlement. The parameters of their political, economic, social and cultural (including religious) lives are drawn from the transnational arena, called the "transnational social field" by Levitt and Schiller (2004).

If migrants were to assimilate as per the expectation of the melting pot metaphor, place making could have become homemaking. If acculturation took place and migrants had been absorbed within the core culture, then the need to bring resources from the transnational social field would not have emerged. Because acculturation failed, for migrants their culture and identity became an important part of the social organisation of space. Migrants often feel a gap between their imagined home and the reality of the new space. Even though they try hard to make the space comfortable, it lacks some of the institutions and resources that give them the sense of comfort they had enjoyed in their homeland. They try to fill or narrow the gap between their imagined home and the reality in the new space by making additional arrangements with the resources they brought with them or that are available to them from their homeland and the transnational arena. This paper calls such arrangements homemaking. Thus, the converting of space into place and then into home involves institutions and the resources that are available to migrants both in the country of settlement and in their transnational social field.

As discussed, the relationships between space, place and home are important to understand how diaspora communities create a home in their new country. This transformation is not an event, but a process, which starts at the time of their arrival and continues to evolve over time. This is also an interactive process between the cultural baggage that members of diaspora communities bring with them, the conditions they face in the new land and the connections they have in the transnational social space. The content of the cultural baggage individual members carry varies in accordance with their social and cultural backgrounds.

\subsection{Transnational ways of being and belonging}

The previous section discussed two different modes of organising space, one with the existing resources and the other with the resources from the transnational social field. These two different modes of organising space are not alternatives or opposites but complementary. In what way are they complementary? The fact is that, for diaspora communities, the creation of a home in the country of settlement, in our case in Norway, cannot be done with only a single way of organising space. As Weingrod and Levy (2005) observe: "Based on lengthy experiences with their hosts, members of these groups are intimately acquainted with the codes of the majority, and yet they also wish to maintain their own 
collective identity, ways of living, and real or imagined connections to their "homeland"'; diaspora communities have thus been maintaining a dual orientation: one towards their country of origin and the other towards their country of settlement. These dual orientations give them a sense of comfort in their new life, and resources from both existing space and the transnational space become relevant in organising the new local space as home.

The resources and practices that are brought from the transnational space and used to create a home have connections with the notions of 'ways of being' and 'ways of belonging', which Levitt and Schiller (2004) have discussed. While discussing migrants' social relations and practices in the transnational social field, they identify two different forms of adaptation among migrants, ways of being and ways of belonging. Ways of being refer "to the actual social relations and practices that individuals engage in rather than to the identities associated with their actions" whereas ways of belonging refer "to practices that signal or enact an identity which demonstrates a conscious connection to a particular group" (ibid: 1010). Here, ways of being denote the social relations and practices that do not consciously contribute to identity formation for the members of migrant communities. As Levitt and Schiller point out, an individual member of a migrant community can follow a practice without any consciousness of identity, but as the routine of day to day life. For example, members of the Tamil or Somali community can eat food with their fingers at home as they did in their countries of origin without any consciousness of the fact that the way they eat contributes to their identity. Actions get more attention than identity with respect to the practices that fall under 'ways of being'. By contrast, in ways of belonging, consciousness of identity is the key feature rather than the actual action. Wearing the hijab as a show of identity is a good example of a practice that falls into the 'ways of belonging' category. This category can also be differentiated as being externally and internally marked, in addition to its other dimensions. (cf Tharmalingam 2010). For instance, wearing specific identity markers to maintain a Muslim identity is an externally marked practice, whereas fasting in the privacy of one's home as a conscientious follower of a particular religion is an internally marked practice.

I have discussed the theoretical aspects of this article so far, at this stage, it is essential to present the empirical materials related to homeland-based cultural practices that are relevant for the scope of this article. The next section deals with it.

\subsection{Homeland-based cultural practices and homemaking - discussion of empirical examples.}

Homeland-based cultural practices are habits culturally rooted in the life style of Tamils and Somalis before they fled their counties of origin. Such practices can be categorised according to different dimensions such as whether they are daily or occasional, individual or collective, strong or weak, visible or less visible, or known or less known (Tharmalingam 2010). Daily practices are those used in day to day life, such as food habits and eating methods, whereas temple festivals and family functions based on homeland traditions, such as wedding and puberty ceremonies, are examples of occasional practices. Individual practices are done alone without the participation of others, collective practices take place with the participation of community members; strong practices strengthen over time, weak practices lose importance; visible practices take place in the public space and are visible to mainstream society, invisible practices are private; and finally, known practices attract the awareness of mainstream society, unknown practices are less well known.

The empirical investigation for this paper asks why Tamils and Somalis adopt homeland-based cultural practices while they are living in Norway. While analysing the interview data, the following have been identified as their reasons for the adoption of homeland-based cultural practices.

1. They are part of their tradition

2. They provide happiness or comfort

3. Relatives in the "homeland" expect them to maintain such practices.

4. Practices reduce nostalgia

5. They provide a sense of belonging

6. They function as identity markers

Fathima, a Somali woman of 47 years old, who has been living in Norway for more than 20 years and who is well integrated with mainstream society, explained in detail why she was keen on carrying out funeral rituals for her mother in the Somali way:

It is important to follow our traditions. When my mother passed away, I was very keen to follow our traditional funeral rituals. We did not have any facilities at my place. I contacted the mosque in Oslo and they sent three persons with all the knowledge and skills to carry out the funeral ritual according to our traditions. It gave us a sense of satisfaction and happiness.

Murugan (46), a Tamil man living in Oslo for more than 25 years, explains his efforts to mix the ashes of his mother with water, which is a part of the Hindu death ritual. The mother had been living in Norway and she was cremated in 
one of the crematoriums in Oslo and her ashes collected. The family kept the ashes with the expectation of taking it to a holy place to mix the ashes with the sea or river, but for practical reasons, finally decided to do it in Oslo.

We could not go to a holy place as we planned earlier. We did not want to keep the ashes for very long with us and decided to carry out the ritual in Norway. I got permission to mix it with the sea at a particular place. We did the ritual in Oslo and that gave us a satisfaction that we have fulfilled our traditional respect to our mother. It gave us a sense of happiness.

Venthan, a 44-year-old Tamil man, revealed that he and one of his friends had lost their mothers and the bodies were cremated in Oslo. But they kept the ashes and took it to Kasi in India for the final ritual at the banks of the holy Ganga River. He expressed his feelings emotionally:

We have to respect the mother who gave us birth and brought us up as good citizens. Let her soul rest in peace.

Practices that fulfill traditions, especially where there are emotional dimensions, have become very important for many of my informants, both Tamils and Somalis, for giving meaning to their life in Norway. For the Somali woman, it was important to hold the funeral rituals in the Somali way. When she did not find the resources to fulfill her wish at home, she called on the support of her religious institution. This institution is an addition to the Norwegian cultural space by the Somali community with the resources they brought from the transnational arenas. There are cases of Tamil funeral rituals that were carried out in Norway by resource persons invited from London. These show how the social and cultural organisation of life by Tamils and Somalis in the Norwegian space transcends the territorial borders of Norway.

In explaining the reasons for many everyday practices including food habits and eating methods, the general view from most of the interviewees is that they follow practices that are known to them, and which they do not want to give up. Abdi, a Somali man in his late sixties, explains this in the following words:

We are different from Norwegians. Ethnically, culturally and physically we are different. It would be difficult to adopt the Norwegian style of living for cultural and religious reasons. For example, I went to a Norwegian party, but I did not eat the food. I only managed to eat salad and pieces of bread.

Amran, a Somali woman, explains the importance of familiar practices in the context of organising family weddings. Such practices give strength to the family. She felt that well-known practices give a kind of ease and comfort. She recalled the response of the family when her brother decided to marry a Norwegian girl as follows:

When my sister got married to a Somali man, we were very happy, and there were ceremonies for a few days. But when my brother decided to marry a Norwegian girl, it was like a bomb blast at our home. She was pretty and very good, but we did not know how to organize the function. When you are forced to handle unfamiliar cultural stuff you become powerless.

Decisions on how to organise homeland-based cultural practices have also some transnational connections when the decision making process transcends the borders of Norway and involves other family members living in other places. Ramu, a Tamil man in his early forties, observes:

Family functions are not always organised in accordance to your own wish. You have to respond to the wishes of your family members in the homeland and other countries. In most cases, the powerful person in the family network has the most influence in deciding the form of the rituals and functions.

Many Tamil and Somali interviewees express feeling happiness and comfort in adopting homeland-based cultural practices. Saraswathi, a Tamil woman in her late sixties, was in a highly emotional state when she explained the importance of the Hindu temple near her home:

After retiring from my work, most of the time I am alone unless I visit a friend or friends come to visit me. The only happiness and satisfaction I have, in addition to this, is at the Hindu temple nearby. I visit the temple regularly and it gives me a sense of home. It is difficult for me to imagine a life without this temple.

The temple the Tamil woman refers to was established as a weekly worship effort in a school hall in the early 1990s. While Tamils decided to live in Norway, this temple became an important cultural institution that gave them a sense of belonging. In Tamil, there is a saying kovil illatha ooril kudiyirukka veendaam: do not live in a place that does not have a temple. The temple initiative got massive support from the Tamils in Norway and soon a permanent building was built and it emerged as a well-established institution. Devotees have been increasing in numbers, and according to the temple officials, they have planned to build a new big temple in another place in Oslo.

Another explanation for engaging in home-based practices is that these practices reduce nostalgia while living in Norway. Somu (49), a Tamil man, narrates his experience: 
We have created a village here in Norway like we lived in back home. The only difference is that this Norwegian Tamil village is a network of families and relatives and friends. They are from different villages in the homeland, 5 from one village, 3 from another, 2 from another and so on. We celebrate functions together as if we were in our homeland and these give us a feeling of home. I do not feel that I am away from home.

Practices have another important dimension as an identity marker. In my interviews, Fathima, a Somali woman said that she deliberately started to wear hijab to transfer the Muslim identity to the children. She said:

I did not wear a hijab until I came to Norway. I started to wear the hijab after my children were born. We wanted to bring our children up with a Muslim identity and it was important to give this identity to the children within the home. Parents are role models for the children and I cannot expect that my children will grow up with a Muslim identity if the mother does not follow traditions.

The reasons that were expressed by the Tamils and Somalis in Norway clearly show that they have been engaging in social organisation of the Norwegian space through cultural practices. Homeland-based cultural practices have a functional value in transforming their new space into home.

\section{Home and homeland}

Through the interview materials we are able to find a distinction between home and homeland. Researches show that most of the second-generation Tamils and Somalis consider Norway their home (Engebrigtsen and Fuglerud 2009, Fangen 2008). Not only for the second generation, many first-generation Tamils and Somalis feel Norway is their home, and make a difference between home and homeland.

Rughman (34), a young adult informant who left Mogadishu when he was 17 years old reflects on the distinction between home and homeland.

Somalia is my homeland. I have no doubt about that. I was born in Somalia and brought up there for 17 years. My home... ahh... Norway is my home...not the whole of Norway... Oslo is my home.

Murugesu, a relatively old Tamil informant, in his late sixties, lives relatively comfortably in Norway. All of his children are in Norway. He claims that he would visit the homeland if it were possible, but he would not return permanently. He preferred to live with his children; besides, he needed the medical facilities available to him in Norway. He expresses his sense of belonging in the following way.

I have been living in Norway for more than 15 years. All of my children live here. I am relatively comfortable here. But my dreams during my sleep are full of images from my homeland. No single image is from Norway. This indicates that though physically I am here, my mind is always in the place where I was born, brought up and lived before.

This little account indicates that even though he lives in Norway relatively comfortably, and although he does not want to return to his homeland permanently, his mind is full of nostalgia. If we conceive the home as a place that gives ease and comfort, Norway should be considered as his home, but he is not mentally settled here in Norway.

Assad, another Somali man in his late thirties, expresses his belonging to Norway in the following words.

I have recently been in African countries for two weeks. I had difficulties in surviving after the first week. I wanted to return to Norway as soon as possible. In one way or another, Norway has become my new home.

This, of course, shows that he considers Norway his new home, but this home includes a Somali community, and Somali cultural and social institutions that create a social and cultural life and network. This new Norway that has a network for Somalis has given him a feeling of home.

Though the members of the Tamil and Somali communities adopt homeland-based cultural practices, there are differences in the adaptation process between individual members. During one of my interviews, I asked Gheidi, a Somali man in his early forties what caused differences in individual behaviour and practices. He responded:

When people migrate, they carry baggage with them. They have different tools in this baggage. This baggage differs from person to person. The behaviour and practices of individuals largely depend on what they have in their baggage.

Sugu, (32) a Tamil youth who came to Norway through a family reunion arrangement says:

There is clear evidence that the practice and behaviour of individuals has been largely shaped by the conditions that prevail in their living places in Norway. It seems to me that Tamils in Bergen are more integrated with Norwegian society than Tamils who live in Oslo. 
As we have seen in the above illustrations, these individual variations in adapting homeland-based cultural practices are mainly attributed to their habitus (Bourdieu 1990) and their position in the transnational social field. Since this is beyond the scope of this paper, I will not go further into the aspects of individual variations.

In the homemaking process, the adaptation of homeland-based cultural practices can fall under both - ways of being and belonging. Many practices and social relations are maintained in the transnational social field without concern for a particular transnational identity (ways of being) and some with specific concerns for identity (ways of belonging). Some practices can fall under both categories, depending upon the context and individuals' perspectives. Building a Caiva temple or a Somali mosque, learning Tamil and Somali languages and the arts, celebrating Caiva temple festivals by Tamils and Eid by Somalis, all are organised and institutionalised practices that are in one sense rooted in their consciousness as part of their transnational identity, but in another, these can also be seen as organising the space in a way that they are used to in their homeland without any concern for a particular transnational identity. In the latter case, these institutions can easily become local institutions rather than transnational ones. Homemaking as the process of making the space comfortable involves both practices of being and belonging.

Practices that belong to ways of belonging are important for Tamils and Somalis. Keeping the new space comfortable is largely dependent on the possibility of following practices that are important in the context of identity formation. Therefore, it seems that it will be difficult to create a comfort space if practices and ways of belonging are contested by mainstream society. Wearing the hijab is a good example of the practice of belonging that gets contested in mainstream society, although the practice is defended by the social and legal institutions of Norway. Tensions around the practice of wearing hijab indicate possible conflicts in making a home in Norway. Though tensions prevail in some areas, it seems that Tamils and Somalis are able to make a space of comfort through homeland-based cultural practices.

Here a question arises. What is the role of particular practices that are largely linked to homeland political issues in making a home in Norway, for example, in celebrating Maaveerar naal (memorial function for fallen Tamil (LTTE) war heroes) in Norway? How do such practices help in establishing a space of comfort? In the case of Maaveerar nall, my observation as a participant in the event is that it helps Tamils in making Norway a comfortable space. The event is organised at the same day and at the same time (November 27) in the Tamil homeland in Sri Lanka and in other places where Tamils live in diaspora communities. ${ }^{2}$ In my view, participating in Maaveerar nall makes them satisfied and comfortable, much more than does viewing videos from the homeland and longing for it with emotions and memories. By participating in the event, all emotions are drained and they start their next day's work at a Norwegian work place with peace of mind. Here, paying respect does not alienate them from the local space, but frees them from emotions and makes them comfortable in the day to day life in Norway. In this sense, I would argue that this practice contributes to making the space comfortable and is thus a component of home making.

As we have seen, the options Tamils and Somalis have for adopting their homeland-based cultural practices contribute to establishing a space of comfort in Norway. On these grounds, it can be argued that homeland-based cultural practices are used by these communities as part of their homemaking process in Norway. Having said that, not all homeland-based cultural practices are helpful in making Norway a home. Besides, cultural practices of diaspora communities are received by the mainstream Norwegian society in two different ways, some are accepted and others are contested in the mainstream cultural space (Eriksen 2006, Tharmalingam 2010).

\section{Concluding remarks}

As we have seen at the beginning of this article through the narration of my search for my childhood home, home is about history, memories and relations. This article has made an attempt to understand the homemaking process of Tamils and Somalis in Norway through an analysis of homeland-based cultural practices. Homeland-based cultural practices, in one-way or another, connect life in Norway with history, memories and relations with the homeland. This article has examined how Tamils and Somalis, having gone through the experiences of losing their home in the country of origin; use their cultural practices to make the new space into a home.

There is a distinction between place making and homemaking: making the new space with the existing institutions and resources is described as place making and the process of adding meaning to the space by bringing resources from the transnational social field is home making. By engaging in homeland-based cultural practices and creating institutions that facilitate such practices, Tamils and Somalis have created a new home for themselves in Norway where they feel comfort and happiness. In this way, Tamils and Somalis have been making changes in the cultural landscape of Norway by establishing their own cultural institutions and practices. Cultural practices function as tools and resources for them

\footnotetext{
${ }^{2}$ After the LTTE was militarily defeated in May 2009, the Sri Lankan government has destroyed LTTE war memorials and memorial events are not allowed. Thus this event takes place only outside of Sri Lanka since last year
} 
in the homemaking process.

In a situation where Tamils and Somalis feel a double belonging - to their country of origin as well as to their new country of settlement, their sense of belonging in Norway depends on how comfortable they can be and live their life in a meaningful way. Generally, it seems and is understood that migrants live a dual life largely without much problems with the mainstream society, though there has been more difficulty for Muslim migrants than for non-Muslim migrants in Norway. Tamils as non-Muslims have some advantages in adapting to mainstream cultural space compared to Somalis who are Muslims. Even though the dual belonging can go parallel, without conflict, it depends on how homemaking process of migrants and their particular ways are viewed by mainstream society. Recent discussions on the frustrated voices of some young Somali girls and on the humiliation they face because of their practice of wearing hijab and their expressions of not wanting to give birth to their children in Norway ring an alarm bell. The supporting voices for these girls in the mainstream public arena show that the hope for a multicultural Norway has a strong foundation.

\section{References}

Ali, N. A., \& Koser, K. E. (2002), New Approaches to Migration: Transnational communities and transformation of home, Routledge: UK.

Agnew, J. (1987). The United States in the world economy: a regional geography Cambridge University Press: Cambridge

Bourdieu, P. (1990). The Logic of Practice, Stanford University Press: Stanford

Cheran. R., Ed. (2006). Multiple Homes and Parallel Civil Societies: Refugee diasporas and transnationalism, Refuge, $23(1 \& 2)$.

Cresswell, T. (2004). Place: A short introduction, Blackwell Publishing: UK.

Douglas, M. (1991). The Idea of Home: A kind of space, Social Research, 58(1), 287-307.

Engebrigtsen, A. I., \& Fuglerud, Ø. (2009). Kultur og generasjon. Tilpasningsprosesser blant somaliere og tamiler $i$ Norge, Universitetsforlaget: Oslo

Eriksen, H. T. (2006). Diversity vs. Differences: Neo-liberalism in the minority debate, in R. Rottenburg, B. Schnepel, S. Shimada (Eds.) The Making \& Unmaking of Difference, 13-36 (Bielefeld: Transaction).

Faist, T. (2000). Transnationalization in International Migration: Implications for the study of citizenship and culture, Ethnic and Racial Studies, 23(2), 189-222.

Fangen, K. (2008). Identitet og praksis. Etnisitet, klasse og kjønn blant somaliere i Norge, Gyldendal akademisk: Oslo

Fuglerud, Ø. (1999). Life on the Outside: Tamil diaspora and long distance nationalism, Pluto Press: London.

Gordon, M. M. (1964). Assimilation in American life: The Role of Race, Religion and National Origins, Oxford University Press: New York

Graham, M., \& Khosravi, S. (1997). Home is Where You Make It: Repatriation and Diaspora Culture among Iranians in Sweden, Journal of Refugee Studies, 10(2), 115-133

Kymlicka, W. (1996) Multi cultural citizenship: A liberal theory of minority rights, Oxford University Press: Oxford:

Itzigsohn, J., \& Saucedo, S. G. (2002), Immigrant Incorporation and Socio-cultural Transnationalism, International Migrant Review, 36(3), 766-798

Levitt, P. (2003). Keeping Feet in Both Worlds: Transnational practices and immigrant incorporation, in C. Joppke and E. Morawska (Eds.) Integrating Immigrants in LiberaI Nation-States: From post-national to transnational, Macmillan-Palgrave: London.

Levitt, P., \& Schiller, G. N. (2004). Transnational Perspectives on Migration: Conceptualizing simultaneity, International Migration Review, 38(3), 1002-1039.

Mallet, S. (2004). Understanding home: critical review of the literature, The Sociological Review, 58(1), 62-89

Morawska, E. (2003). Immigrant Transnationalism and Assimilation: A variety of combinations and the analytic strategy it suggests, in C. Joppke and E. Morawska (Eds.) Toward Assimilation and Citizenship: Immigrants in Liberal Nation-States, Palgrave, Macmillan: UK, 133-176

Park, R. E. (1928). Human Migration and the Marginal Man, American Journal of Sociology, 33(6), 881-893.

Portes, A., \& Zhou, M. (1993). The New Second Generation: Segmented Assimilation and its Variants, The ANNALS of the American Academy of Political and Social Science, 530(1), 74-96 
Saunders, P., \& Williams, P. (1988). The Constitution of the Home: Towards a research agenda, Housing Studies 3(2): 81-93

Short, J. R. (1999). Foreword. In At Home: An anthropology of domestic space, Cieraad, Irene, ed., Syracase University Press: New York.

Tambiah, S. J. (2000). Transnational movements, diaspora, and multiple modernities, Daedalus, 129(1), 163-194

Tharmalingam, S. (2010). Dynamics of Mutual Cultural Incorporation between the Majority and Minorities in Norway, Unsubmitted manuscript.

Weingrod, A., \& Levy, A. (2005). On Homelands and Diasporas: An introduction, in Andre Levy \& Alex Weingrod (Eds.) Homelands and Diasporas: Holy Lands and Other Places, Stanford University Press: California.

Wise, J. M. (2000). Home: Territory and identity, Cultural Studies, 14(2), 295-310

Yeoh, S. A., Brenda, Charney, W. M., \& Kiong, T. C. E. (2003). Approaching Transnationalisms; Studies on transnational societies, multicultural contracts, and imaginings of home, Kluwer Academic Publishers: Massachusetts

\section{(cc) $\mathrm{EY}$}

This work is licensed under a Creative Commons Attribution 3.0 License. 